\title{
Seasonal and longitudinal variation in fish assemblage structure along an unregulated stretch of the Middle Uruguay River
}

\author{
Marthoni Vinicius Massaro ${ }^{1}$, Lucas Adriano Pachla ${ }^{1}$, Rodrigo Bastian ${ }^{1}$, \\ Fernando Mayer Pelicice ${ }^{2}$ and David Augusto Reynalte-Tataje ${ }^{1}$
}

Diversity patterns and their causes remain important questions, especially for ecosystems that preserve natural conditions. This is the case of fish diversity in large Neotropical rivers. In this context, we investigated fish diversity patterns along an extensive unregulated river section $(\mathrm{ca} .450 \mathrm{~km})$ in the Middle Uruguay River Basin. Sampling was conducted seasonally between May 2017 and March 2018, at six sites (patches) with contrasting environmental conditions. We collected 3,008 individuals belonging to 90 species. Nine were migratory, which summed relevant biomass in local assemblages (20 to $60 \%)$. We observed spatial variation in assemblage structure, but weak seasonal effects. Overall, biomass was similar among sites, but richness tended to increase downstream. Migratory fishes showed opposed trends, with higher richness and biomass upstream, particularly catfishes (Siluriformes). Ordination analyses separated sites in three groups based on variations in composition and abundance, and revealed associations between these groups and specific hydro-geomorphic conditions (i.e., flow, depth, channel width and the presence of riparian vegetation). Our study revealed that fish diversity distributes heterogeneously along the main channel, where hydro-geomorphic patches select for distinct assemblages along riverine gradients.

Keywords: Diversity, Floodplain, Migratory fish, Riparian vegetation, River channel.

Os padrões de diversidade e suas causas continuam sendo questões importantes, especialmente em ecossistemas que preservam condições naturais. Este é o caso da diversidade de peixes em grandes rios neotropicais. Neste contexto, investigamos padrões de diversidade de peixes ao longo de um extenso gradiente fluvial ( $c a .450 \mathrm{~km})$ no médio rio Uruguai. As amostragens ocorreram sazonalmente entre maio/2017 e março/2018 em seis locais com condições ambientais distintas. Coletamos 3.008 indivíduos pertencentes a 90 espécies. Nove eram migradoras, as quais somaram relevante biomassa nas assembleias locais (20 a 60\%). Houve variação espacial na estrutura das assembleias, mas fraco efeito sazonal. No geral, a biomassa foi semelhante entre os locais, mas a riqueza tendeu a aumentar em direção a jusante. Peixes migradores apresentaram padrão inverso, com maior riqueza e biomassa a montante, especialmente bagres (Siluriformes). Análises de ordenação separaram os locais em três grupos de acordo com a variação na composição e na abundância, e revelaram correlação entre esses grupos e condições hidro-geomorfológicas específicas (i.e., velocidade, profundidade, largura do canal e vegetação riparia). Nosso estudo revelou que a diversidade de peixes se distribui de maneira heterogênea ao longo do canal, onde características hidrogeomorfológicas selecionam assembleias distintas ao longo de gradientes fluviais.

Palavras-chave: Canal do rio, Diversidade, Peixes migradores, Planície aluvial, Vegetação Ripária.

\section{Introduction}

Understanding the main processes that affect the structure of fish communities remains an important challenge (Jackson et al., 2001; Costa, Freitas, 2015). In large river systems, fish diversity distributes heterogeneously across different spatiotemporal gradients, including longitudinal, lateral, altitudinal and seasonal dimensions (Humphries et al., 2014). The Patch Dynamics Concept applied to river ecosystems (Pringle et al., 1988; Winemiller et al., 2010), in particular, explains lotic environments as hierarchical and dynamic mosaics of interconnected patches (i.e., habitats), where organisms disperse and colonize according to their niche attributes. At intermediate spatial scales (i.e.,

\footnotetext{
${ }^{1}$ Universidade Federal da Fronteira Sul (UFFS), Av. Prof. Jacob Reinaldo Haupenthal, 1580, 97900-00 Cerro Largo, RS, Brazil. (MVM) bio.marthonivinicius@gmail.com, @https://orcid.org/0000-0003-3816-6623 (Corresponding author), (LAP) lucas.pachla@hotmail.com, ๑https://orcid.org/0000-0003-1381-7477, (RB) robastian@gmail.com, ○https://orcid.org/0000-0001-8868-7457, (DART) david.tataje@, uffs.edu.br, @https://orcid.org/0000-0002-9853-4830.

${ }^{2}$ Núcleo de Estudos Ambientais, Universidade Federal do Tocantins, 77500-000 Porto Nacional, TO, Brazil. (FMP) fmpelicice@gmail.com, (Dhttps://orcid.org/0000-0002-9700-1194.
} 
hundreds of kilometers), the main channel of large rivers is heterogeneous and dynamic, formed by arrays of large hydro-geomorphic patches such as constricted, braided and floodplain channel areas, with relevant spatiotemporal variation in flow patterns, depth, sediment, connectivity and primary production (McCluney et al., 2014). Hydrological and geomorphological processes are key factors, because they create a mosaic-type riverscape with some longitudinal orientation (Ward, Tockner, 2001; Scarabotti et al., 2017). According to this view, fish diversity respond to this arrangement of fluvial patches (Hoeinghaus et al., 2004; Foubert et al., 2018), which provide habitats for different life-strategies (Altermatt, 2013) and work as dispersal routes for migratory fishes (Makrakis et al., 2012).

However, few aquatic ecosystems remain free from human disturbances. Anthropic activities modified the functioning of most large rivers, with detrimental effects on aquatic biodiversity (Naiman, Dudgeon, 2011; Ballesteros et al., 2017). The main disturbances include hydrological alterations, habitat loss, pollution, invasive species and overexploitation (Agostinho et al., 2005). These disturbances have affected fish diversity (Pelicice et al., 2017), especially when they induce changes in the structure and distribution of habitat patches along the river, causing species losses, population declines and strong shifts in composition and functional traits (Agostinho et al., 2016; Arantes et al., 2017). Migratory fishes, in particular, have been significantly affected by river regulation and other impacts, and populations are currently suppressed or extirpated from some stretches and basins (Hoeinghaus et al., 2009; Loures, Pompeu, 2018; Pelicice et al., 2018). In the Neotropical region, few large rivers preserve their fluvial pristine conditions. This is especially true for the La Plata Basin, the second main basin in South America, where human development is expressive (e.g., industry, urbanization, agriculture, hydropower) (Luz-Agostinho et al., 2008; Petesse, Petrere, 2012; Smith et al., 2018).

Notable exceptions are the Paraguay-Paraná axis (Quirós et al., 2007; Rabuffetti et al., 2016) and the Uruguay River Basin (Zaniboni-Filho, Schulz, 2003), which still preserve long unregulated sections. Both systems offers the possibility to understand how fish diversity distributes along large rivers in the La Plata Basin. The Uruguay, in particular, extends over $1,800 \mathrm{~km}$ from south Brazil to the La Plata River (Uruguay), near the Atlantic Ocean. This basin has three geomorphological domains (i.e., Upper, Middle and Lower (Zaniboni-Filho, Schulz, 2003)), marked by the presence of natural physical barriers (e.g., waterfalls) and different hydro-geomorphic patches (e.g., constricted channels with rapids or deep pools) along its main course, a conformation that probably contributed to generate a high fish diversity [275 fish species; (Bertaco et al., 2016)]. The Uruguay river is currently subjected to several disturbances (e.g., dams, pollution, deforestation), but the middle reach still preserves significant lotic segments with riparian vegetation: a long fluvial stretch (ca. $900 \mathrm{~km}$ ) is found between Foz do Chapecó and Salto Grande dams. The presence of this free-flowing section, which is formed by a mosaic of hydro-geomorphic patches, offers the opportunity to understand fish diversity patterns in lotic corridors of the La Plata Basin.

In this scenario, we investigated fish diversity (species richness, abundance and composition) along an extensive fluvial gradient $(c a .450 \mathrm{~km})$ in the Middle Uruguay River. In particular, we analyzed the response of fish species to habitat variation along the river corridor, a section characterized by different hydro-geomorphological conditions and landscape structure, i.e., the presence of constricted channels in the form of shallow rapids or deep pools, and floodplain areas. Variation in flow, depth, channel width and the presence of riparian vegetation, for example, must select for specific local assemblages. In this sense, based on the Patch Dynamics Concept applied to river ecosystems (Pringle et al., 1988; Winemiller et al., 2010), we predict spatial discontinuity in fish diversity patterns (i.e., distinct local assemblages along the river corridor), where assemblage structure is associated with hydro-geomorphic patches (e.g., constricted channels or floodplain areas). In this sense, we expect that macrohabitat conditions, particularly spatial (e.g., location) and geomorphological factors (e.g., depth, width), explain fish assemblage structure. In particular, we expect higher fish biomass and richness in floodplain patches, where conditions are more variable and habitat diversity is high (Junk et al., 1989). Moreover, we expect significant seasonal variation in fish diversity, considering that hydrological dynamics affect the structure of habitat patches (Humphries et al., 2014), inducing changes in local assemblages. Finally, considering that this river section is unregulated, we predict that migratory fishes are regular components of local assemblages, summing relevant fraction of fish biomass - contrasting with patterns observed in highly regulated basins, where migratory fishes are rare or absent (Loures, Pompeu, 2018; Pelicice et al., 2018).

\section{Material and Methods}

Study area. The Uruguay River is divided into three regions (Upper, Middle and Lower Uruguay), which are separated by physical barriers. Salto do Yucumã Fall, located inside the Turvo State Park (Brazil), is the division between the Upper and Middle Uruguay. The Salto Grande Dam, located in the border between Argentina and Uruguay, divides the Middle from the Lower Uruguay. Currently, large and small dams regulate the Upper Uruguay section.

The Middle Uruguay River is characterized by a long fluvial segment (approximately $900 \mathrm{~km}$ ), with riparian forests in both margins (Brazil-Argentina border). This segment has two important protected areas, the Yaboti Biosphere Reserve (Argentina) and the Turvo State Park (Brazil); human activities, however, have induced some disturbances, including the loss of riparian vegetation, 
urbanization and overfishing. The middle Uruguay is characterized by a width ranging from $280 \mathrm{~m}$ in the most upstream stretch, to $2,000 \mathrm{~m}$ in the region near Salto Grande HPP. It has an average slope of $9 \mathrm{~cm} / \mathrm{km}$, which is more marked in the upper region, where the Atlantic Forest Biome predominates (Zaniboni-Filho, Schulz, 2003). The lower reach, downstream from the municipality of São Borja, contains a floodplain area and belongs to the Pampa Biome.
Sampling design. Samples were collected at six sites, to cover a spatial extent of $450 \mathrm{~km}$ (Fig. 1) and to encompass a long river gradient with different hydro-geomorphic patches: constricted channel with shallow rapids, constricted channel with deep pools, and a floodplain. The characterization of the sampling sites is shown in Tab. 1 and Tab. S1 - Available only as supplementary file accessed with the online version of the article at http:// www.scielo.br/ni.

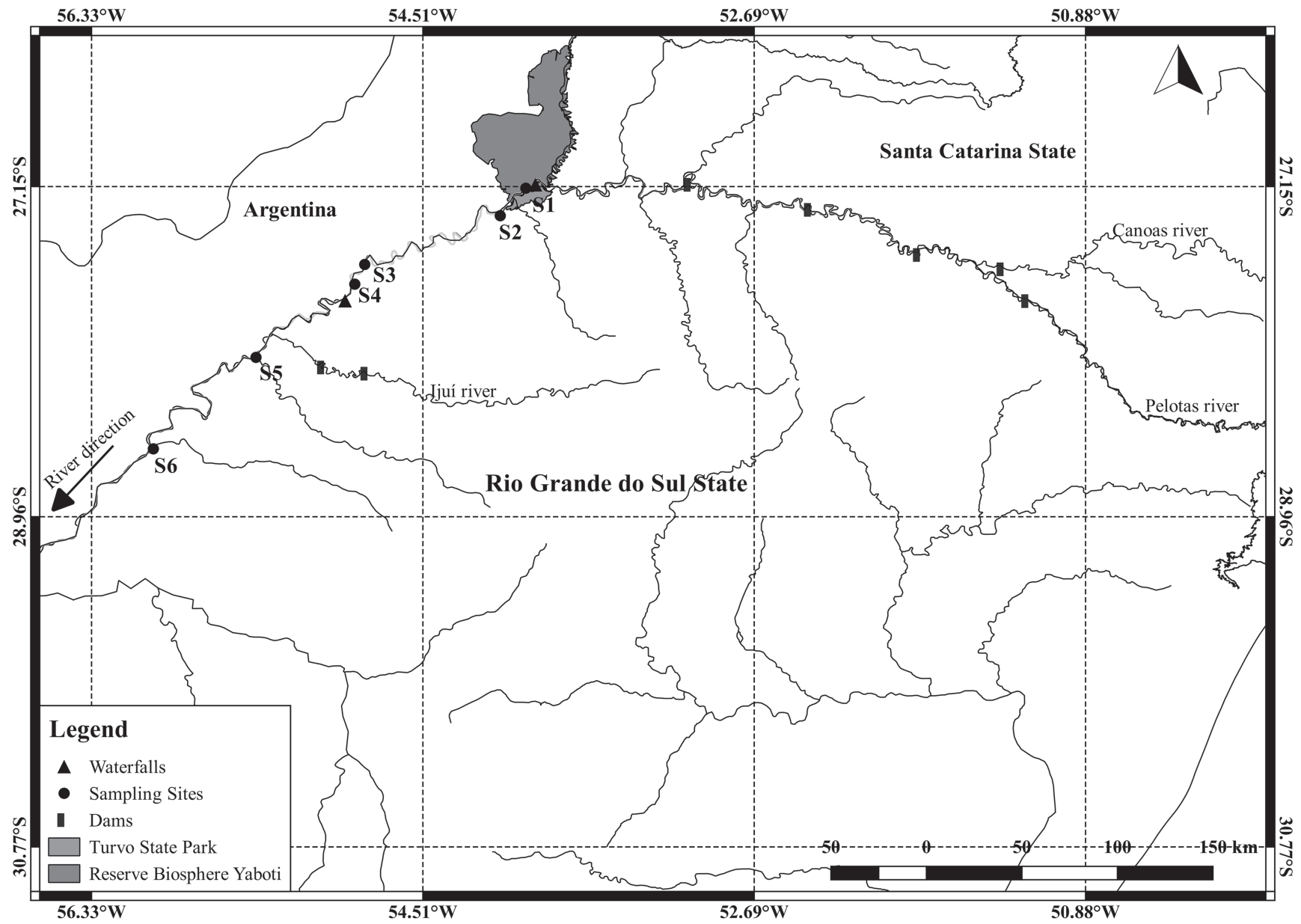

Fig. 1. Location of sampling sites along the Middle Uruguay River, RS, Brazil. Derrubadas (S1), Esperança do Sul (S2), Alecrim (S3), Porto Vera Cruz (S4), São Nicolau (S5) and São Borja (S6).

Tab. 1. Information about sampling sites along the Middle Uruguay River, Brazil. *Distance from the beginning of the Middle Uruguay River Basin. **Percentage of riparian forests covering a $10 \mathrm{~km}^{2}$ long river section.

\begin{tabular}{|c|c|c|c|c|c|c|c|c|}
\hline $\begin{array}{l}\text { Sampling site } \\
(*)\end{array}$ & $\begin{array}{l}\text { Habitat } \\
\text { description }\end{array}$ & \multicolumn{2}{|c|}{ Coordinates } & $\begin{array}{l}\text { Width } \\
(\mathrm{m})\end{array}$ & $\begin{array}{l}\text { Depth } \\
(\mathrm{m})\end{array}$ & $\begin{array}{l}\text { Altitude } \\
(\mathrm{m})\end{array}$ & $\begin{array}{l}\text { Riparian Vegetation } \\
(\%)^{* *}\end{array}$ & $\begin{array}{l}\text { Municipality } \\
\text { (RS, Brazil) }\end{array}$ \\
\hline S1 $(16$ km) & Rapids and pools & $27^{\circ} 10^{\prime} 64^{\prime \prime S}$ & $53^{\circ} 54^{\prime} 31^{\prime \prime} \mathrm{W}$ & 280 & $3 / 12$ & 135 & 98 & Derrubadas \\
\hline S2 (41 km) & Pools & $27^{\circ} 18^{\prime} .70^{\prime \prime S}$ & $54^{\circ} 06^{\prime} 33^{\prime \prime} \mathrm{W}$ & 405 & 18 & 123 & 8 & Esperança do Sul \\
\hline S3 (175 km) & Pools & $27^{\circ} 34^{\prime} .26^{\prime \prime} \mathrm{S}$ & $54^{\circ} 49^{\prime} 55^{\prime \prime} \mathrm{W}$ & 840 & 14 & 96 & 15 & Alecrim \\
\hline S4 (217 km) & Rapids & $27^{\circ} 42^{\prime} .01^{\prime \prime} \mathrm{S}$ & $54^{\circ} 53^{\prime} 47^{\prime \prime} \mathrm{W}$ & 790 & 3 & 91 & 18 & Porto Vera Cruz \\
\hline S5 (332 km) & Rapids & $28^{\circ} 04^{\prime} .44^{\prime \prime} \mathrm{S}$ & $55^{\circ} 25^{\prime} 38^{\prime \prime} \mathrm{W}$ & 1230 & 4 & 69 & 19 & São Nicolau \\
\hline S6 (450 km) & Floodplain and pools & $28^{0} 34^{\prime} .15^{\prime \prime} \mathrm{S}$ & $56^{\circ} 0.9^{\prime} 51^{\prime \prime} \mathrm{W}$ & 1250 & $2 / 19$ & 52 & 6 & São Borja \\
\hline
\end{tabular}


Data collection. A total of 24 field trips were carried out seasonally between May 2017 and March 2018. Different fishing gears were employed to maximize fish capture, covering littoral, benthic and pelagic habitats. Fish were collected using a set of gillnets with different mesh sizes $(20,30,40,50,80 \mathrm{~mm}$ between adjacent knots), $10 \mathrm{~m}$ long and $2.0 \mathrm{~m}$ high. Using a total of $20 \mathrm{~m}^{2}$ of net of each mesh. We also used two longlines, $100 \mathrm{~m}$ long, 30 hooks each (hooks 5/0 and 12/0), baited with small fish, corn and snail. All set of fishing gears remained deployed for 12 hours, mainly overnight. Gillnets were used to capture fish close to riverbanks, while the longline targeted pelagic and carnivorous fish. Additionally, we hauled a seine ( 0.8 $\mathrm{cm}$ mesh-size, $10 \mathrm{~m}$ long and $2 \mathrm{~m}$ high) over littoral areas, totaling three samples at each site per trip. To calculate Capture per Unit Effort (CPUE), we considered only fish captured by gill nets. Species captured with longlines and seines were used to evaluate assemblage composition and richness.

Specimens were fixed in 10\% formalin and preserved in $70 \%$ ethanol. Species were identified according to Zaniboni-Filho et al. (2004), and voucher specimens will be deposited in the Fish Collection at the State University of Maringá, Paraná, Brazil. This study is part of project 534 entitled "Fish Ecology of the Middle Uruguay", carried out under permits 55011-2 (ICMBio) and 104/2017 (Secretaria do Meio Ambiente e Infraestrutura do Estado do Rio Grande do Sul). This last permit allowed fish sampling in protected areas (Turvo State Park).

Habitat descriptors. We characterized habitat condition at each site by measuring limnological, land cover, spatial and geomorphological variables. The following limnological variables were recorded during each sampling occasion: $\mathrm{pH}$, electrical conductivity $\left(u \mathrm{~S} . \mathrm{cm}^{-1}\right)$, dissolved oxygen $\left(\mathrm{mg} . \mathrm{l}^{-1}\right)$, water temperature $\left({ }^{\circ} \mathrm{C}\right)$, current velocity $\left(\mathrm{m} \cdot \mathrm{s}^{-1}\right)$, transparency $(\mathrm{cm})$ and water level $(\mathrm{m})$. These measurements were made at the surface using a multiparameter device and a flowmeter. Water transparency was measured with a Secchi disk, and water level with a level rule fixed at the shore. All limnological variables were measured simultaneously with fish sampling. For each site, we recorded the following geomorphological descriptors: river width, mean depth and altitude. Average depth was obtained from three measurements made at each sampling site. Width, distance and altitude were measured from georeferenced satellite images in Google Earth Pro (Google, Menlo Park, California). We also calculated the distance of each site to the beginning of the sub-basin (Middle Uruguay), as a proxy of spatial position along the river channel. Finally, we calculated the percentage of riparian vegetation covering each site. For this, an area of $10 \mathrm{~km}^{2}$ (10 km long and $0.5 \mathrm{~km}$ of each river side) was considered at each margin of the sampling site. This calculation was performed using the program Fragstats package v.4.0.
Migratory species classification. Fish species were classified as migratory or non-migratory following specific literature (e.g., Carosfeld et al., 2003; Agostinho et al., 2007; Reynalte-Tataje, Zaniboni-Filho, 2008; Makrakis et al., 2012). Migratory fishes have complex life cycles and migrate over long distances $(>100 \mathrm{~km})$ between feeding and spawning sites. Non-migratory fishes, on the other hand, include a variety of behaviors, e.g., sedentary, short-distance displacements, rheophilic, limnophilic; reproductive dynamics differ from patterns observed for migratory species, since they demand smaller geographic ranges to complete their life cycles. All analyses focused on the entire community and migratory fishes.

Data analyses. Fish assemblage structure was described as abundance, species richness and composition. Abundance (individuals) and biomass (kilograms) were expressed as catch per unit effort $\left(\right.$ CPUEn $=$ ind. $/ 100 \mathrm{~m}^{2}$ of net; $\mathrm{CPUEb}$ $=\mathrm{Kg} / 100 \mathrm{~m}^{2}$ of net). Species richness is the number of species in each sample, and composition refers to the taxonomic identity of species.

We run nonparametric analysis of variance (KruskallWallis) to evaluate differences in CPUEb and species richness among sites and seasons, followed by Dunn's $a$ posteriori test. We chose a non-parametric test because variance was not homogeneous. We conducted a Detrended Correspondence Analysis (DCA) to ordinate samples based on species abundance and composition. This analysis was conducted to depict variation in fish fauna structure among sites and seasons. A Multiple Response Permutation Procedure (MRPP) was carried out to verify the consistency, significance and homogeneity among groups (sites and seasons).

To investigate the importance of limnological, temporal and geo-spatial variables explaining fish assemblage structure, we conducted a variation partitioning approach. This procedure calculates pure and shared components of variation resulting from different sets of explanatory variables (Anderson, Gribble, 1998). We considered three sets of variables: 1) Limnological: $\mathrm{pH}$, temperature, dissolved oxygen, electrical conductivity, water transparency, level and velocity; 2) Temporal (seasons): autumn, winter, spring and summer, included as four binary variables; 3) Geo-spatial: depth, altitude, width, riparian forest cover and distance from the beginning of the sub-basin. This analysis employs a two-step approach: (i) Canonical Correspondence Analyses (CCA) to select main variables from the different sets of explanatory variables (limnological, temporal and geo-spatial), and (ii) a partial CCA (pCCA) to investigate the correlation between assemblage structure and main variables selected (Borcard et al., 1992; Peres-Neto et al., 2006). This approach is valuable to reduce the number of possible predictors, simplifying the investigation and restricting analyses to main factors behind environmental variation. The selection of limnological variables, for example, is 
evidence that some local conditions (microhabitat) affect habitat selection by fishes. The selection of geo-spatial predictors, on the other hand, points to the existence of hydro-geomorphic patches that determine the distribution of fish diversity.

First, we run separate CCAs on each set of explanatory variables (limnological, temporal and geo-spatial). A Monte Carlo procedure (999 permutation) was applied to test the significance of each variable in the species-environment relationships. The forward selection procedure was used to reduce multicollinearity in the limonological and geo-spatial datasets. Second, combining all significant variables from each CCA, we run a pCCA to partition the variation explained by each variable on fish abundance. The variation explained was reported as percentage of total variation explained (TVE), calculated as the ratio between the sum of all canonical eigenvalues and total inertia. Statistical significance implied $p<0.05$. All analyzes were carried out in PCORD version 5, Statistic version 7.1 and CANOCO version 5.
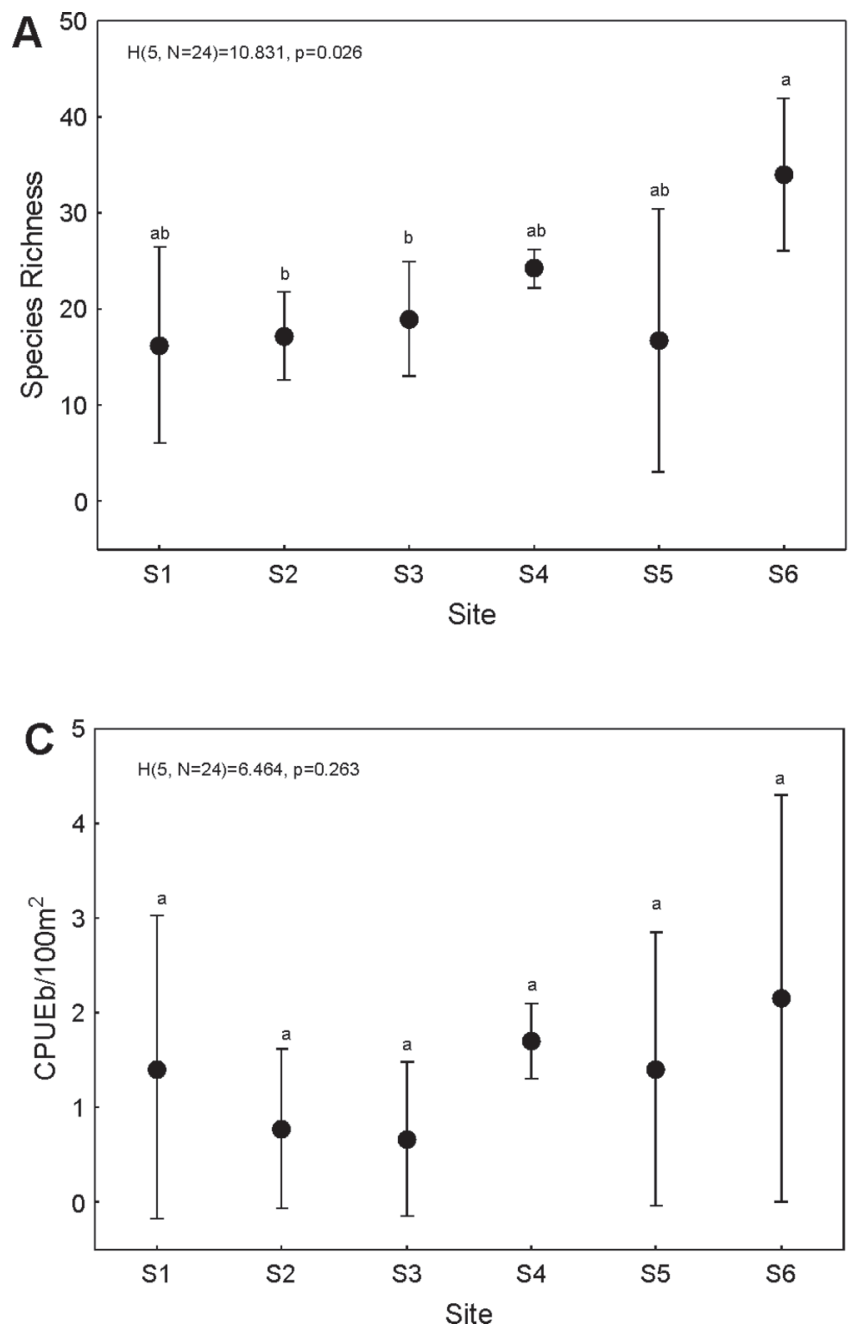

\section{Results}

Fish assemblage structure. We recorded 3,008 individuals belonging to 90 species, 27 families and 10 orders (Tab. S2 - Available only as supplementary file accessed with the online version of the article at http://www.scielo. br/ni). Characiformes and Siluriformes were the most representative orders, with $42(46.6 \%)$ and $32(35.6 \%)$ species respectively. Most species belonged to the families Characidae (22), Loricariidae (13) and Pimelodidae (8). The most abundant species were Iheringichthys labrosus (11\% of total abundance) and Leporinus amae (10\%). Nine species were assigned as migratory (10\% of total richness). We observed spatial and temporal variation in fish richness and biomass. Species richness tended to increase downstream, with higher values at site S6 (Fig. 2A); richness did not vary significantly among seasons (Fig. 2B). Fish biomass (CPUE) were similar among sites (Fig. 2C), but changed significantly among seasons, with higher values during the spring (Fig. 2D).
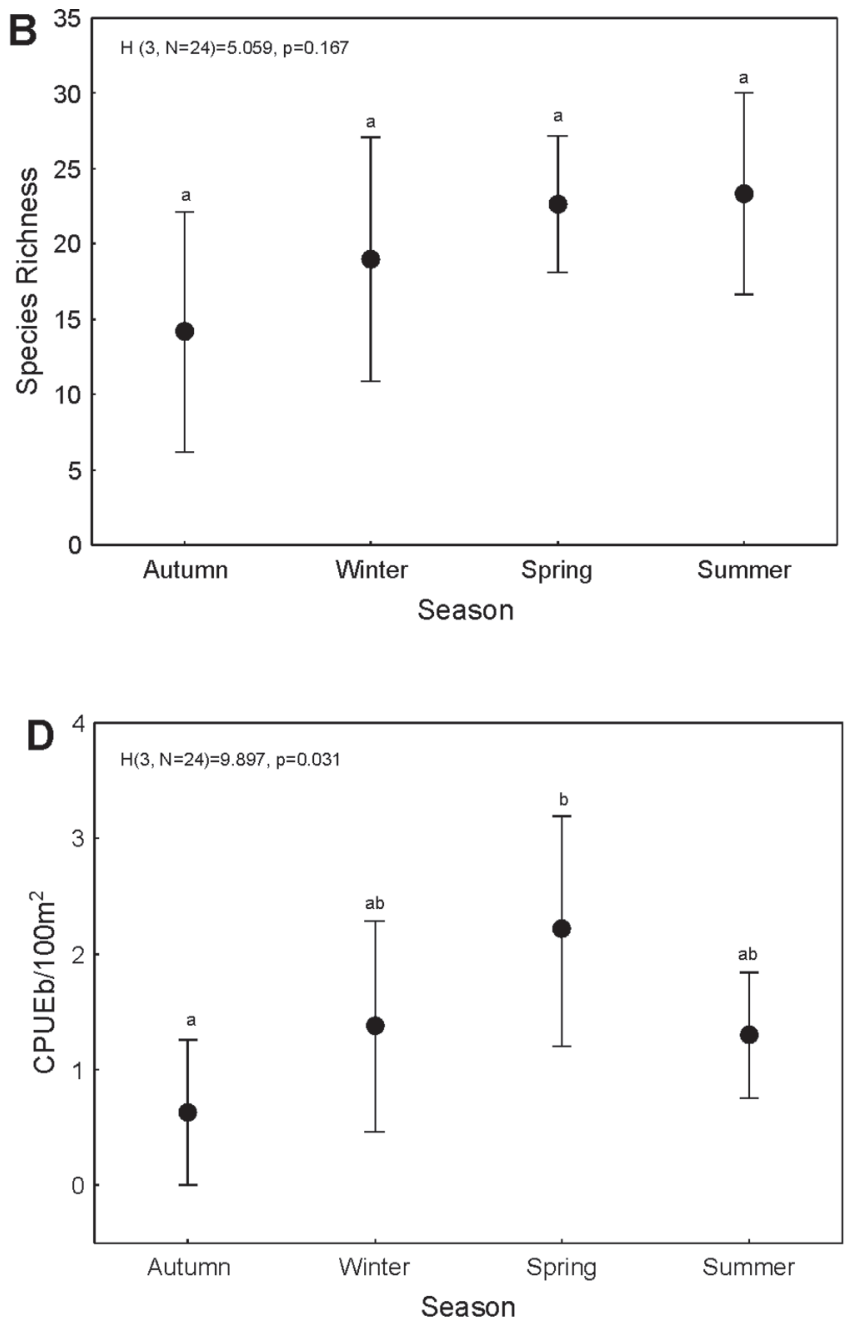

Fig. 2. Variation (mean \pm standard deviation) in species richness and biomass (CPUEb/100 $\mathrm{m}^{2}$ ) along the river channel (A and C) and among seasons (B and D), in the Middle Uruguay River. Sites: S1 = upstream; S6 = downstream. Different letters indicate statistical difference $(\mathrm{p}<0.05)$. 
Considering migratory fishes, the number of species differed among sites, with higher values at site S1 (Fig. 3A); no temporal effect was observed (Fig. 3B). Fish biomass (CPUE) showed higher values at site S1 (Fig. 3C) and during the spring (Fig. 3D). The proportion (relative biomass) of migratory fishes at each site was variable, but they summed at least $20 \%$ of all biomass (Fig. 4A); higher fractions $(>50 \%)$ were observed at sites S1 and S5. Siluriformes were more abundant at sites upstream, while Characiformes tended to be widely distributed in the study area (Fig. 4B).

The DCA summarized spatial variation in fish composition and abundance (Fig. 5). The proportion of variance explained was 0.42 for Axis 1 and 0.22 for Axis 2 . The ordination revealed three main groups: sites $\mathrm{S} 2+\mathrm{S} 3$, sites $\mathrm{S} 1+\mathrm{S} 4+\mathrm{S} 5$, and site $\mathrm{S} 6$. Axis 1 was affected primarily by Prochilodus lineatus $(\mathrm{r}=-0.49)$, Salminus brasiliensis $(\mathrm{r}=-0.54)$, Steindachnerina brevipinna $(\mathrm{r}=-0.52)$, Astyanax lacustris $(\mathrm{r}=-0.59)$, Astyanax fasciatus $(\mathrm{r}=$ -0.44), Loricariichthys anus $(\mathrm{r}=0.42)$ and Iheringichthys labrosus $(\mathrm{r}=0.40)$. Axis 2 was affected mainly by
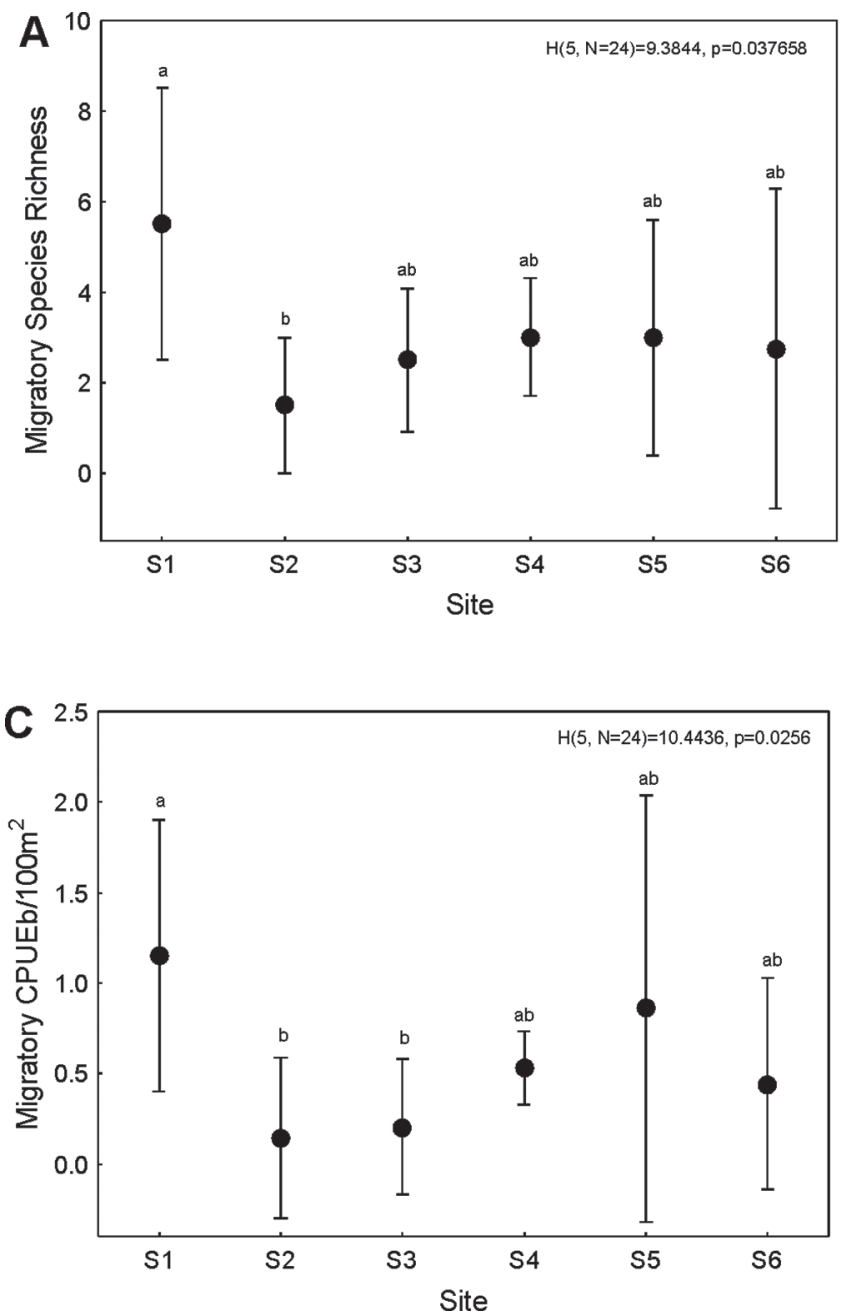

Pachyurus bonariensis $(\mathrm{r}=-0.46)$, Iheringichthys labrosus $(\mathrm{r}=-0.43)$, Rhinodoras dorbignyi $(\mathrm{r}=0.69)$, Pimelodus maculatus $(\mathrm{r}=0.48)$ and Ageneiosus militaris $(\mathrm{r}=0.50)$. MRPP analysis confirmed the spatial pattern, revealing the same three groups: sites $\mathrm{S} 1+\mathrm{S} 4+\mathrm{S} 5$, sites $\mathrm{S} 2+\mathrm{S} 3$ and S6 (Tab. 2). The DCA showed no clear pattern concerning seasons (Fig. 5), and the MRPP confirmed no difference among seasons $(\mathrm{T}=-1.43 ; \mathrm{A}=0.04 ; \mathrm{p}<0.20)$.

Association with environmental variables. The forward selection method in each CCA selected three limnological variables $(\mathrm{pH}$, temperature and velocity) and most geo-spatial variables (depth, width, riparian forest and distance). The pCCA run with these variables explained $30.2 \%$ (TVE) of the total variation in species abundance $($ Total inertia $=2.805)$. Geo-spatial variables explained $29.5 \%$ of total variation, limnological explained $18.7 \%$, and temporal explained $16.7 \%$ (Tab. 3). Geo-spatial variables explained the largest fraction of TVE, considering either non-overlapping components or components shared with other variable sets (co-variables).
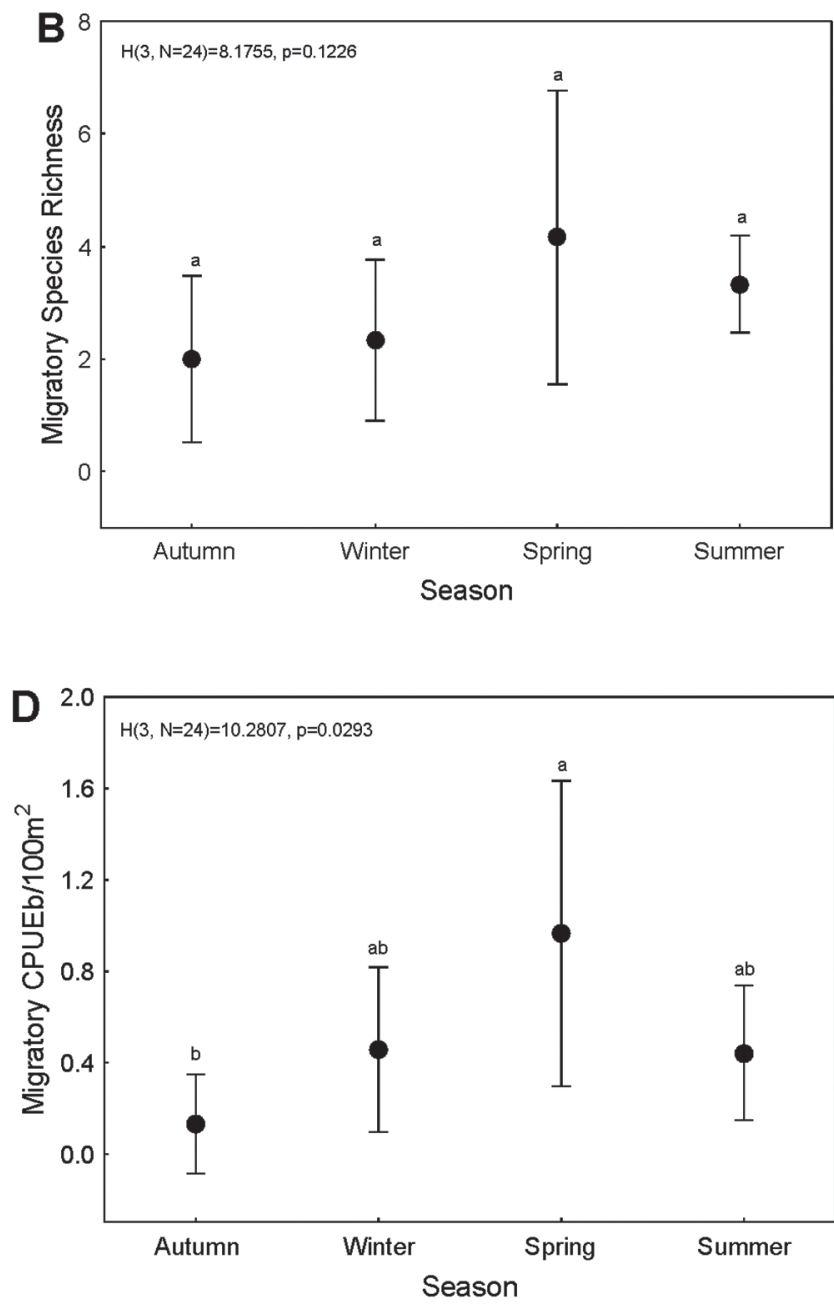

Fig. 3. Variation (mean \pm standard deviation) in species richness and biomass $\left(\mathrm{CPUEb} / 100 \mathrm{~m}^{2}\right)$ of migratory fishes along the river channel (A and C) and among seasons (B and D), in the Middle Uruguay River. Sites: S1 = upstream; S6 = downstream. Different letters indicate statistical difference $(\mathrm{p}<0.05)$. 

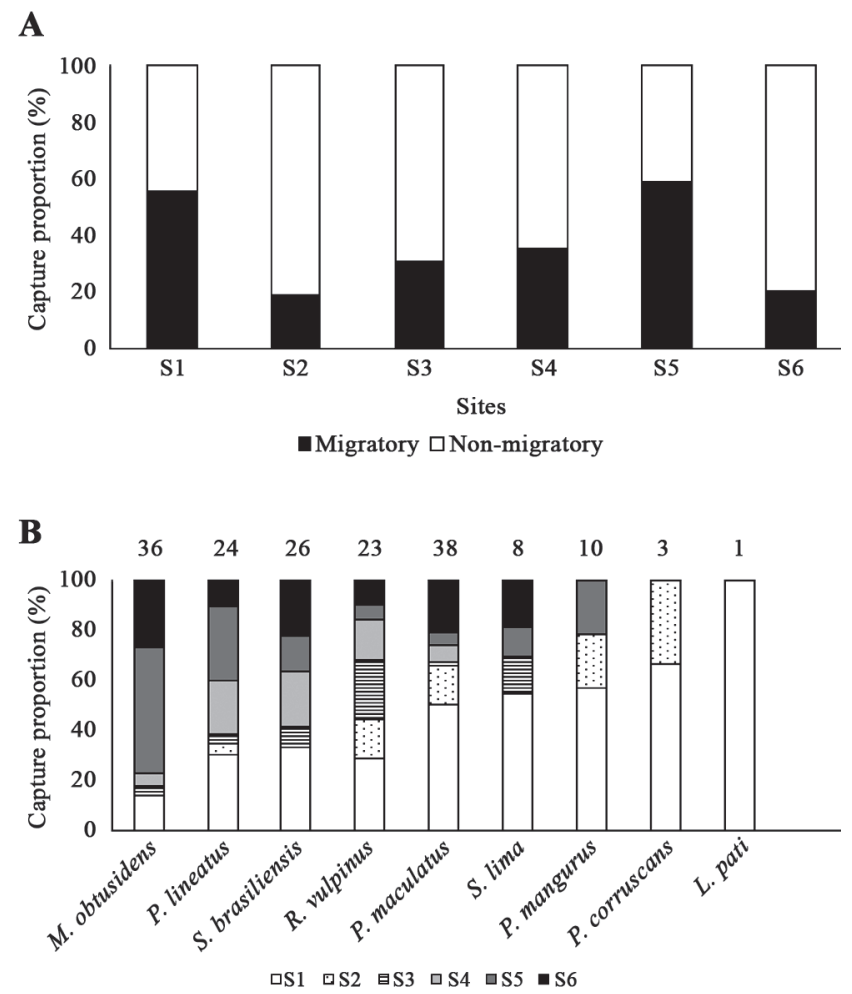

Fig. 4. Relative abundance (\% biomass, CPUEb) of migratory fishes at each site (A), and spatial distribution of biomass considering each migratory species (B). The number of individuals captured is indicated above each bar. Characiformes: Megaleporinus obtusidens, Prochilodus lineatus, Salminus brasiliensis and Rhaphiodon vulpinus. Siluriformes: Pimelodus maculatus, Sorubim lima, Pseudopimelodus mangurus, Pseudopplatystoma corruscans and Luciopimelodus pati.

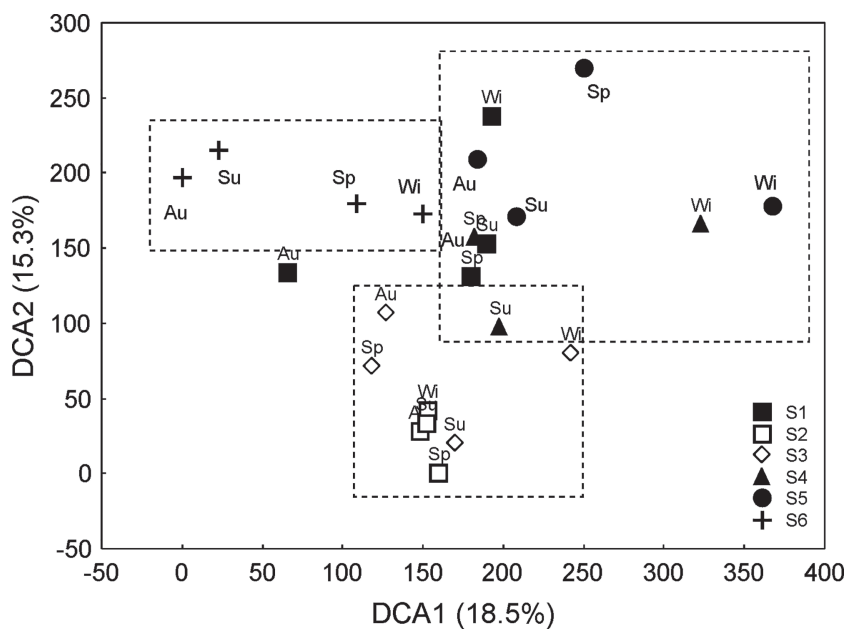

Fig. 5. Detrended Correspondence Analysis (DCA) applied to ordinate samples according to variations in fish composition and abundance along the Uruguay River. Rectangles depict groups confirmed by a Multiple Response Permutation Procedure (Tab. 2). Sites: S1 = upstream; S6 $=$ downstream. Seasons: $\mathrm{Au}=$ Autumn; $\mathrm{Sp}=$ Spring; $\mathrm{Su}=$ Summer and $\mathrm{Wi}=$ Winter.
Tab. 2. Results of the MRPP analysis, which compared fish assemblage composition (CPUEn) between sites. Bold $\mathrm{t}$-values indicate statistical differences $(\mathrm{p}<0.05)$.

\begin{tabular}{|c|c|c|c|c|c|c|}
\hline SITES & S1 & S2 & S3 & S4 & S5 & S6 \\
\hline S1 & & -1.45 & -1.95 & -0.15 & 0.77 & -1.45 \\
\hline S2 & & & 0.58 & -1.84 & -1.54 & -1.97 \\
\hline S3 & & & & -2.37 & -1.51 & -2.51 \\
\hline S4 & & & & & -0.89 & -1.42 \\
\hline S5 & & & & & & 0.47 \\
\hline
\end{tabular}

Tab. 3. Results of the Partial Canonical Correspondence Analysis (pCCA) showing the total variation explained (TVE) for fish abundance data by each set of explanatory variables $(\mathrm{L}=$ Limnological, $\mathrm{T}=$ Temporal and $\mathrm{GS}=$ Geo-Spatial) and their corresponding non-overlapping components of variation. $\% \mathrm{TVE}=$ percentage of total variation explained by each component.

\begin{tabular}{lcc}
\hline Variables & Co-variables & $\%$ TVE \\
\hline Set of variables & & 18.7 \\
\hdashline L & & 16.7 \\
T & & 29.5 \\
GS & & \\
\hdashline Non-overlapping components & T*GS & 9.4 \\
\hdashline L & L*GS & 7.9 \\
T & T*L & 19.1 \\
GS & GS & 0.4 \\
L*T & T & 3.2 \\
L*GS & L & 2.8 \\
T*GS & & 0.3 \\
L*T*GS & & \\
\hline
\end{tabular}

The set of geo-spatial variables correlated significantly with species abundances (Monte Carlo test; $\mathrm{p}<0.05$ ). Limnological and temporal variables did not correlate. Considering only geo-spatial variables, the first two axis (Fig. 6) separated the same three groups observed in the DCA and MRPP. The distribution of sites along the first axis was influenced by river width $(r=-0.72)$ and distance $(\mathrm{r}=-0.98)$, while the distribution along the second axis was affected mainly by depth $(\mathrm{r}=0.74)$ and riparian vegetation $(\mathrm{r}=-0.79)$. Several species associated with positive and negative scores in each axis, but migratory species were placed in the lower right quadrant (Fig. 6); it indicates that migratory species are associated with sites S1, S4 and S5, correlating with moderate depth and width, riparian forest cover and the presence of rapids, i.e., a constricted channel with the presence of rapids. The most distinct assemblages, however, occurred at site S6, where the river channel is wide, i.e., a floodplain. 

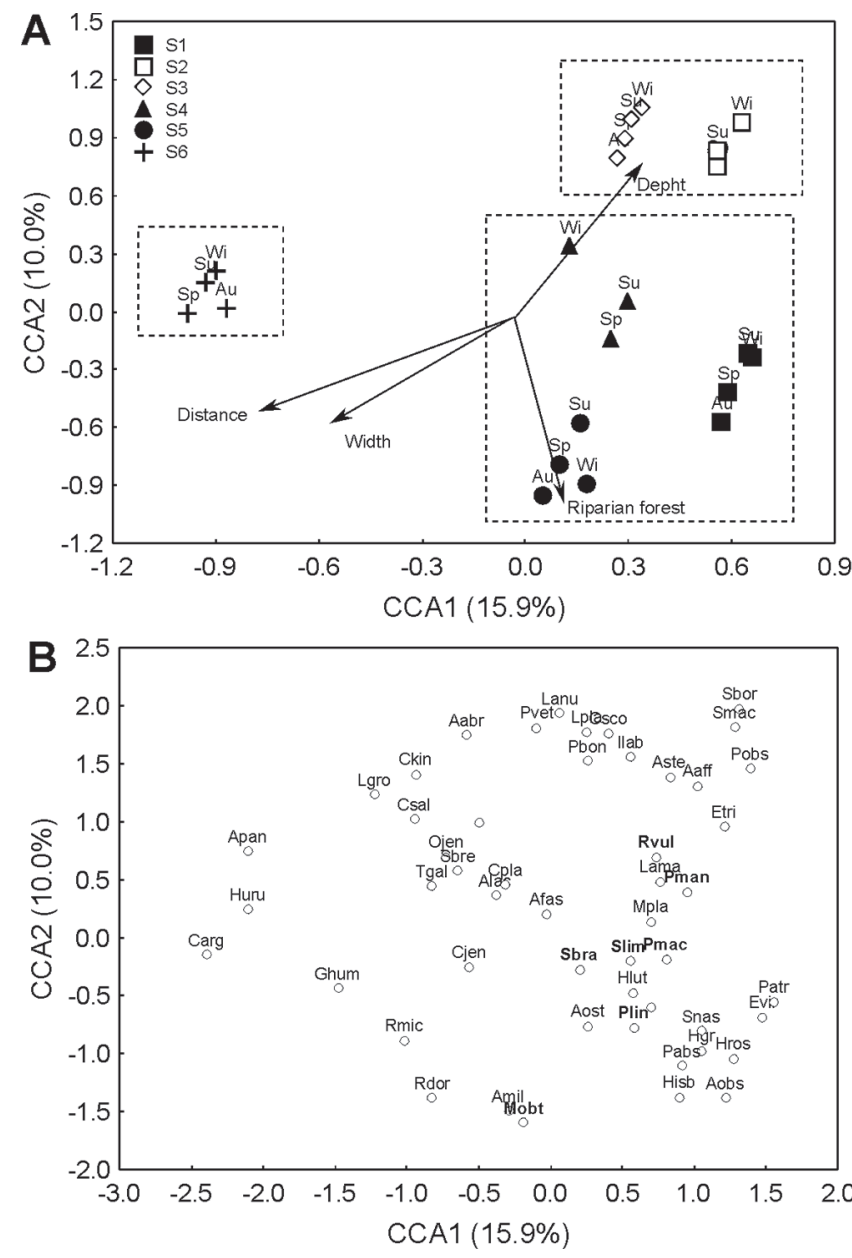

Fig. 6. Canonical Correspondence Analysis (CCA) applied to investigate the association between fish assemblage structure and environmental variables (spatial, geomorphology and landscape) along the Middle Uruguay River (A), and the influence of species on the ordination (B). Seasons: $\mathrm{Au}=$ Autumn; $\mathrm{Sp}=$ Spring; $\mathrm{Su}=$ Summer and $\mathrm{Wi}=$ Winter. Migratory species are marked in bold.

\section{Discussion}

The Middle Uruguay River has a long fluvial segment (ca. $900 \mathrm{~km}$ ) free from dams. Our study, the first conducted in this region, covered a relevant river stretch $(c a .450 \mathrm{~km})$ and included considerable variation in geomorphological conditions and landscape structure, i.e., the presence of constricted channels with shallow rapids or deep pools, and a floodplain. We assumed the Patch Dynamics Concept (Winemiller et al., 2010) as a theoretical background, and predicted spatial discontinuity in fish diversity patterns along the river corridor. Confirming this expectation, we observed significant spatial variation in assemblage structure (i.e., richness, abundance, biomass and composition). One important result is that macro-habitat features (i.e., geomorphology, spatial and landscape variables) explained most variation in species distribution, while limnological and seasonal factors exerted little influence.
These results indicate that specific hydro-geomorphic conditions (patches) along riverine gradients select for distinct assemblages, supporting the prediction that spatial and hydro-geomorphological factors play a major role in determining the distribution of fish diversity. Another important finding was the prominence of migratory species in local assemblages, confirming the expectation that theses fishes are common and abundant in unregulated rivers. In general, our results indicate that the Patch Dynamics Concept, i.e., lotic systems as mosaics of interconnected and variable patches, provides a valuable background to explain fish diversity patterns in fluvial corridors at intermediate spatial extents ( $c a$. hundreds of kilometers).

Fish species distributed heterogeneously along the river, and correlated with hydro-geomorphic, spatial and landscape attributes, i.e., channel width, depth, the presence of riparian forests and conditions related to flow and slope (presence of rapids, pools and floodplains). These factors determine macro-habitat conditions, which have strong effects on fish diversity (Torrente-Vilara et al., 2011; Carvajal-Quintero et al., 2015; Arantes et al., 2017; Foubert et al., 2018), and aquatic diversity in general (Ward, Tockner, 2001; Thorp et al., 2006). Ordination analyses (DCA, CCA) supported this view, because sites were combined in three groups with specific hydro-geomorphic conditions and fauna structure. Sites of the first group (S1, S4 and S5) were more canalized and shallow (i.e., rapids), surrounded by riparian vegetation, where migratory species predominated. In the second group (S2 and S3), riparian vegetation was rare, the channel was deeper and flow was slower (i.e., pools); the third group (S6) was a floodplain area. Therefore, these contrasting hydrogeomorphic conditions create habitat patches with specific environmental features, selecting for assemblages with different species composition. Dispersal between patches is probably another driver, because there is no strong physical barrier among sites, and fish species recorded have different dispersal modes and abilities. For example, rheophilic and migratory fishes move frequently along the river (Vitorino Júnior et al., 2016), while sedentary fishes may find some resistance (Hrbek et al., 2018). Results therefore support the view that large rivers are systems with multiple habitat patches linked by aquatic corridors (i.e., Patch Dynamics Concept), where fish species disperse and colonize according to their niches demands and dispersal abilities (Altermatt, 2013).

The importance of macro-habitat conditions was evident for the third group (S6), the only located in a floodplain area. This region has a distinct phytogeographic structure, because it belongs to the Pampa Biome, where riparian vegetation is naturally scarce and rice crops are common. At this site, we observed higher species richness (60 species in total). Floodplain areas tend to provide a diversity of microhabitats and food resources, allowing the coexistence of several species (Araújo, Tejerina-Garro, 2007; Súarez, 2008). In addition, due to the input of allochtonous material (i.e., flooding) and high aquatic productivity (e.g., macrophytes), floodplains provide adequate habitats for 
different life-strategies. For example, some small-sized species (e.g., Aphyocharax anisitsi and Roeboides affinis) and juvenile of migratory fishes (e.g., Salminus brasiliensis and Megaleporinus obtusidens; unpublished data) were captured only at this site. However, fish biomass was not as high as expected, although some samples showed high values. High fish biomass is typical in floodplains, but these ecosystems are also characterized by environmental variability, dictated by the hydrological regime (Junk et al., 1989). Moreover, migratory fishes, which are large-bodied, predominated in constricted channels, not in the floodplain area. Therefore, floodplain features likely determined the peculiar assemblage found in the downstream section of the study area.

We predicted seasonal variation in fish fauna structure, considering that hydrological dynamics have strong effects on environmental conditions in habitat patches (Humphries et al., 2014). In fact, studies have shown that fish diversity varies temporally in subtropical environments (Agostinho et al., 2007; Scarabotti et al., 2017). This prediction, however, was not confirmed. This trend is likely associated with the climatic condition of the studied year (i.e., La Niña phenomenon), which experienced mild variations in water flow and temperature. Weak environmental variation may have affected seasonal processes that induce variation to community structure, such as migration, predation, resource availability and mortality (Winemiller, Jepsen, 1998; González-Bergonzoni et al., 2016; Fitzgerald et al., 2017). We also point out that the Uruguay river lacks a well-defined rainy season, since rains fall over the year (concentrated in spring and summer) and floods are swift and not intense (Zaniboni-Filho, Schulz, 2003). These features probably minimized seasonal variation in abiotic and biotic conditions. The exception was a weak but significant increase in fish biomass during the spring, a trend probably driven by the movement of migratory fishes, since their biomass also increased during this season. Migratory behavior is variable in the Uruguay river basin, but some species start their spawning migration during the spring (Zaniboni-Filho, Schulz, 2003), in response to spring rains, a climatic feature of the basin (Reynalte-Tataje et al., 2017).

Migratory species were important components of local assemblages, summing relevant biomass in lotic sites and confirming our prediction that these fishes are abundant in unregulated sections of the La Plata basin. It differs from impounded areas, where migratory fishes are numerically scant or absent (Agostinho et al., 2008; Petesse, Petrere, 2012; Reynalte-Tataje et al., 2012; Loures, Pompeu, 2018; Pelicice et al., 2018). The trend reported here, therefore, may resemble conditions found in more pristine environments, and serve as a baseline pattern for comparisons and impact assessment. However, migratory fishes distributed heterogeneously in the studied segment. Higher biomass and richness were observed in sites with lotic conditions, i.e., constricted shallow channels, with the presence of rapids and riparian vegetation. In addition, fish orders showed different spatial distribution. While Siluriformes concentrated in upstream sites, particularly at S1, Characiformes were captured along the entire gradient, indicating that these fishes either disperse more easily along the river corridor or find suitable conditions at different patches. This differential distribution (Siluriformes vs. Characiformes) depicts a diversified behavior among migratory species - usually assigned as a single monotypic group. Other studies have shown a diversity of migratory patterns (Godinho, Kynard, 2008; Makrakis et al., 2012; Barthem et al., 2017; Lopes et al., 2018), and our data indicate that these fishes display specific preferences, choosing distinct patches along the fluvial corridor. We just highlight that fish migration (i.e., stimuli and movement) might have been affected by limited rainfall and lower water levels during the study period, considering that the Yacumã Falls work as a natural barrier during dry periods (Zaniboni-Filho, Schulz, 2003); in fact, migratory fishes were more abundant at $\mathrm{S} 1,50 \mathrm{~km}$ downstream from this barrier.

The presence of migratory species in the region is important indication that the Middle Uruguay River is a hotspot of migratory diversity, with relevance for the whole La Plata Basin. This record is important because migratory fishes support commercial, recreational fisheries and ecossystem function (Hoienghaus et al., 2009; Días et al., 2019). Some populations seem to find suitable habitats for permanence and recruitment, especially because the area has critical habitats (long riverine segment, tributaries and floodplain). It includes protected areas, where relevant riparian forests remain, i.e., Turvo State Park and Yaboti Biosphere Reserve (Ribolli et al., 2018), and spawning grounds (Reynalte-Tataje et al., 2017). The absence of dams in this long river segment is the most relevant factor, but we note that large dams regulate the main channel of the Upper and Lower Uruguay. This condition may have negative effects on ecological dynamics in the Middle Uruguay, especially if these dams block migratory routes. In fact, three migratory species are listed as endangered in a regional red list (Rio Grande do Sul, 2014), namely Brycon orbignyanus, Pseudoplatystoma corruscans and Salminus brasiliensis. The present study recorded $S$. brasiliensis in all sites, but $P$. corruscans was rare (three individuals). Salminus brasiliensis is considered vulnerable in the Middle Uruguay, where fishing is banned since 2002; populations of $P$. corruscans are rarefied, reflecting its critical state in the basin. Habitat degradation, caused by the construction of dams, the loss of critical habitats, siltation and pollution, in addition to the increasing fishing pressure, may explain this situation.

Currently, the largest rivers in South America are regulated by cascades of dams (Pelicice et al., 2015; Agostinho et al., 2016). Dams modify hydro-geomorphic conditions along river channels, change the natural flow regime and decrease hydrological connectivity, causing significant disturbances to fish populations (Petrere Jr, 1996; Orsi, Britton, 2014; Lima et al., 2016; Loures, Pompeu, 
2018). The Middle Uruguay River is an important fluvial remnant in the La Plata Basin, but hydropower development is planned to occur in the region (i.e., Garabi-Panambi Hydropower Complex). If it succeeds, we predict significant changes in fish diversity, with the proliferation of sedentary, generalists and/or opportunists species, and the decline ofmigratory species. In this sense, the maintenance of fluvial conditions, particularly the mosaic-type riverscape along the middle Uruguay River, including tributaries and protected areas, is crucial to preserve fish diversity in the region.

\section{Acknowledgments}

The authors thank FAPERGS for providing a scholarship, and Federal University of Fronteira Sul (UFFS) for providing infrastructure. $\mathrm{CNPq}$ provided a research grant for Fernando M. Pelicice.

\section{References}

Agostinho AA, Gomes LC, Pelicice FM. Ecologia e manejo de recursos pesqueiros em reservatórios do Brasil. Maringá: EDUEM; 2007.

Agostinho AA, Gomes LC, Santos NCL, Ortega JCG, Pelicice FM. Fish assemblages in Neotropical reservoirs: Colonization patterns, impacts and management. Fish Res. 2016; 173(1):26-36. http://doi.org/10.1016/j.fishres.2015.04.006

Agostinho AA, Thomaz SM, Gomes LC. Conservação da biodiversidade em águas. Megadiversidade. 2005; 1(1):70-78.

Altermatt F. Diversity in riverine metacommunities: A network perspective. Aquat Ecol. 2013; 47(3):365-77. http://doi. org.10.1007/s10452-013-9450-3

Anderson MJ, Cribble NA. Partitioning the variation among spatial, temporal and environmental components in a multivariate data set. Austral Ecol. 1998; 23(2):158-67. https://doi.org/10.1111/j.1442-9993.1998.tb00713.x

Arantes CC, Winemiller KO, Petrere M, Castello L, Hess LL, Freitas CEC. Relationships between forest cover and fish diversity in the Amazon River floodplain. J Appl Ecol. 2017; 55(1):386-95. http://doi.org/10.1111/1365-2664.12967

Araújo NB, Tejerina-garro FL. Composição e diversidade da ictiofauna em riachos do Cerrado, bacia do ribeirão Ouvidor, alto rio Paraná, Goiás, Brasil. Rev Bras Zool. 2007; 24(4):98190. http://doi.org/10.1590/S0101-81752007000400014

Ballesteros ML, Rivetti NG, Morillo DO, Bertrand L, Amé MV, Bistoni MA. Multi-biomarker responses in fish (Jenynsia multidentata) to assess the impact of pollution in rivers with mixtures of environmental contaminants. Sci Total Environ. 2017; 595(1):711-22. http://doi.org/10.1016/j. scitotenv.2017.03.203

Barthem RB, Goulding M, Leite RG, Cañas C, Forsberg B, Venticinque E, Petry P, Ribeiro MLDB, Chuctaya J, Mercado A. Goliath catfish spawning in the far western Amazon confirmed by the distribution of mature adults, drifting larvae and migrating juveniles. Sci Rep. 2017; 7(1):1-13. http://doi. org.10.1038/srep41784
Bertaco VA, Ferrer J, Carvalho FR, Malabarba LR. Inventory of the freshwater fishes from a densely collected area in South America - A case study of the current knowledge of Neotropical fish diversity. Zootaxa. 2016; 4138(3):401-40. http://doi.org/10.11646/zootaxa.4138.3.1

Borcard D, Legendre P, Drapeau P. Partialling out the spatial component of ecological variation. Ecology. 1992; 73(3):1045-55. https://doi.org/10.2307/1940179

Carosfeld J, Harvey B, Ross C, Baer A. Migratory fishes of the South América: Biology, social importance and conservation status. Victoria: World Fisheries Trust; 2003.

Carvajal-Quintero JD, Escobar F, Alvarado F, Villa-Navarro FA, Jaramillo-Villa U, Maldonado-Ocampo JA. Variation in freshwater fish assemblages along a regional elevation gradient in the northern Andes, Colombia. Ecol Evol. 2015; 5(13):2608-20. http://doi.org/10.1002/ece3.1539

Costa ID, Freitas CEC. Factors determining the structure of fish assemblages in an Amazonian river near to oil and gas exploration areas in the Amazon basin (Brazil): establishing the baseline for environmental evaluation. Zool. 2015; 32(5):351-59. http://doi.org/10.1590/S198446702015000500004

Díaz S, Pascual U, Stenseke M, Martín-López B, Watson RT, Molnar Z, Hill R, Chan KMA et al. Assessing nature's contributions to people. Recognizing culture, and diverse sources of knowledge, can improve assessments. Science. 2019; 359(6373): 270-72. Available from: Doi: 10.1126/ science.aap 8826

Fitzgerald DB, Winemiller KO, Sabaj Pérez MH, Sousa LM. Using trophic structure to reveal patterns of trait-based community assembly across niche dimensions. Funct Ecol. 2017; 31(5):1135-44. https://doi.org/10.1111/1365-2435.12838

Foubert A, Lecomte F, Legendre P, Cusson M. Spatial organisation of fish communities in the St. Lawrence River: a test for longitudinal gradients and spatial heterogeneities in a large river system. Hydrobiologia. 2018; 809(1):155-73. http:// doi.org/10.1007/s10750-017-3457-z

Godinho AL, Kynard B. Migratory fishes of Brazil: Life history and fish passage needs. River Res Appl. 2008; 25(6):702-12. http:// doi.org/10.1002/rra.1180

González-Bergonzoni I, Jeppesen E, Vidal N, Teixeira-de Mello F, Goyenola G, López-Rodríguez A, Meerhoff M. Potential drivers of seasonal shifts in fish omnivory in a subtropical stream. Hydrobiologia. 2016; 768(1):183-96. https://doi. org/10.1007/s10750-015-2546-0

Hoeinghaus DJ, Agostinho AA, Gomes LC, Pelicice FM, Okada EK, Latini JD, Kashiwaqui EAL, Winemiller KO. Effects of river impoundment on ecosystem services of large tropical rivers: Embodied energy and market value of artisanal fisheries. Conserv Biol. 2009; 23(5):1222-31. http://doi. org/10.1111/j.1523-1739.2009.01248.x

Hoeinghaus DJ, Winemiller KO, Taphorn DC. Compositional change in fish assemblages along the Andean piedmont Llanos floodplain gradient of the río Portuguesa, Venezuela. Neotrop Ichthyol. 2004; 2(2):85-92. http://doi.org/10.1590/ S1679-62252004000200005 
Hrbek T, Meliciano NV, Zuanon J, Farias IP. Remarkable geographic structuring of rheophilic fishes of the lower Araguaia River. Front Genet. 2018; 9(Aug):1-12. http://doi. org/10.3389/fgene.2018.00295

Humphries P, Keckeis H, Finlayson B. The river wave concept: Integrating river ecosystem models. Bioscience. 2014; 64(10):870-82. http://doi.org/10.1093/biosci/biu130

Jackson DA, Peres-Neto PR, Olden JD. What controls who is where in freshwater fish communities the roles of biotic, abiotic, and spatial factors. Can J Fish Aquat Sci. 2001; 58(1):157-70. http://doi.org/10.1139/f00-239

Junk W, Bayley P, Sparks R. The flood pulse concept in RiverFloodplain systems. Can Spec Publ Fish Aquat Sci. 1989; 106(1):110-27.

Lima AC, Agostinho CS, Sayanda D, Pelicice FM, Soares AMVM, Monaghan KA. The rise and fall of fish diversity in a neotropical river after impoundment. Hydrobiologia. 2016; 763(1):207-21. http://doi.org. 10.1007/s10750-015-2377-z

Lopes JM, Pompeu PS, Alves CBM, Peressin A, Prado IG, Suzuki FM, Facchin S, Kalapothakis E. The critical importance of an undammed river segment to the reproductive cycle of a migratory Neotropical fish. Ecol Freshw Fish. 2018; 1(1):1-15. http://doi.org/10.1111/eff.12454

Loures RC, Pompeu PS. Long-term study of reservoir cascade in south-eastern Brazil reveals spatio-temporal gradient in fish assemblages. Mar Freshw Res. 2018; 69(12): 1983-94. http:// doi.org/10.1071/MF18109

Luz-Agostinho DGK, Agostinho AA, Gomes LC, Júlio HF. Influence of flood pulses on diet composition and trophic relationships among piscivorous fish in the upper Paraná River floodplain. Hydrobiologia. 2008; 607(1):187-98. Available from: doi.org.10.1007/s10750-008-9390-4?

Makrakis MC, Miranda LE, Makrakis S, Fontes Júnior HM, Morlis WG, Dias JHP, Garcia JO. Diversity in migratory patterns among Neotropical fishes in a highly regulated river basin. J Fish Biol. 2012; 81(2):866-81. http:// doi.org/10.1111/j.10958649.2012.03346.x

McCluney KE, Poff NL, Palmer MA, Thorp JH, Poole GC, Williams BS, Williams MR, Baron JS. Riverine macrosystems ecology: Sensitivity, resistance, and resilience of whole river basins with human alterations. Front Ecol Environ. 2014; 12(1):48-58. http://doi.org/10.1890/120367

Naiman RJ, Dudgeon D. Global alteration of freshwaters: Influences on human and environmental well-being. Ecol Res. 2011; 26(5):865-73. http:// doi.org.10.1007/s11284-010-0693-3

Orsi ML, Britton JR. Long-term changes in the fish assemblage of a neotropical hydroelectric reservoir. J Fish Biol. 2014; 84(6):1964-70. http:// doi.org/10.1111/jfb.12392

Pelicice FM, Azevedo-Santos VM, Esguícero ALH, Agostinho AA, Arcifa MS. Fish diversity in the cascade of reservoirs along the Paranapanema River, southeast Brazil. Neotrop Ichthyol. 2018; 16(2):e170150. http:// doi.org/10.1590/1982-0224-20170150

Pelicice FM, Azevedo-Santos VM, Vitule JRS, Orsi ML, Lima Junior DP, Magalhães ALB, Pompeu PS, Petrere M, Agostinho AA. Neotropical freshwater fishes imperilled by unsustainable policies. Fish Fish. 2017; 18(6):1119-33. http://doi.org/10.1111/faf.12228
Pelicice FM, Pompeu PS, Agostinho AA. Large reservoirs as ecological barriers to downstream movements of Neotropical migratory fish. Fish Fish. 2015; 16(4):697-715. http://doi. org/10.1111/faf.12089

Peres-Neto PR, Legendre P, Dray S, Borcard D. Variation partitioning of species data matrices: Estimation and comparison of fractions. Ecology. 2006; 87(10):2614-25. http://doi.org/10.1890/00129658(2006)87[2614:VPOSDM]2.0.CO;2

Petesse ML, Petrere Jr M. Tendency towards homogenization in fish assemblages in the cascade reservoir system of the Tietê river basin, Brazil. Ecol Eng. 2012; 48(1):109-16. http://doi. org/10.1016/j.ecoleng.2011.06.033

Petrere Jr M. Fisheries in large tropical reservoirs in South America. Lakes Reserv Res Manag. 1996; 2(1):111-33. http:// doi.org/10.1111/j.1440 1770.1996.tb00054.x

Pringle CM, Naiman RJ, Bretschko G, Karr JR, Oswood MW, Webster JR, Welcomme RL, Winterbourn MJ. Patch dynamics in lotic systems: The stream as a mosaic. J North Am Benthol Soc. 1988; 7(4):503-24.

Quirós R, Bechara JA, Resende EK. Fish diversity and ecology, habitats and fisheries for the un-dammed riverine axis Paraguay-Parana-Rio de la Plata (Southern South America). Aquat Ecosyst Heal Manag. 2007; 10(2):187-200. https://doi. org/10.1080/14634980701354761

Rabuffetti A, Górski K, Espínola L, Abrial E, Amsler M, Paira A. Long-Term hydrologic variability in a large subtropical floodplain River: Effects on commercial fisheries. River Res Appl. 2016; 33(3):353-63. https://doi.org/10.1002/rra.3100

Reynalte-Tataje D, Barcellos R, Hartmann P, Scherer J, Martine G, Vlieger I, Zaniboni-Filho E, Hermes-Silva S, Pelicice FM. O Médio rio Uruguai como importante área de reprodução do surubim-pintado Pseudoplatystoma corruscans (Siluriformes: Pimelodidae). Bol - Soc Ictiol Londrina. 2017; 122(1):10-15.

Reynalte-Tataje D, Zaniboni-Filho E, Hermes Silva S, Machado C, Guereschi R, Nuñer A. Assembleia de peixes. In: Nuñer APO, Zaniboni-Filho E, editors. Reservatório de Machadinho. Peixes, pesca e tecnologias de criação. Florianópolis: Editora da UFSC; 2012. p.11-44.

Reynalte-Tataje DA, Zaniboni-Filho E. Biologia e identificação de ovos e larvas de peixes do alto rio Uruguai, Brasil. In: Zaniboni-Filho E, Nuñer APO, editors. Reservatório de Itá. Estudos ambientais, desenvolvimento de tecnologias de cultivo e conservação da ictiofauna. Florianópolis: Editora da UFSC; 2008. p.139-54.

Ribolli J, Zaniboni-Filho E, Freitas PD, Galetti PM. Genetic evidences of non-reproductive shoaling in the freshwater fish Salminus brasiliensis. Hydrobiologia. 2018; 815(1):65-72. http://doi.org/10.1007/s10750-018-3550-y

Rio Grande Do Sul. Decreto Estadual n ${ }^{\circ} 51.797$, de 08 setembro de 2014. Declara as espécies da fauna silvestre ameaçadas de extinção no Rio Grande do Sul. Porto Alegre: Diário Oficial; 2014. p.2-12.

Scarabotti PA, Demonte LD, Pouilly M. Climatic seasonality, hydrological variability, and geomorphology shape fish assemblage structure in a subtropical floodplain. Freshw Sci. 2017; 36(3):653-68. http://doi.org/10.1086/693441 
Smith WS, Stefani MS, Espíndola ELG, Rocha O. Changes in fish species composition in the middle and lower tietê river (São paulo, brazil) throughout the centuries, emphasizing rheophilic and introduced species. Acta Limnol Bras. 2018; 30(1): e310. http://doi.org/10.1590/s2179-975x0118

Súarez YR. Variação espacial e temporal na diversidade e composição de espécies de peixes em riachos da bacia do rio Ivinhema, alto rio Paraná. Biota Neotrop. 2008; 8(3):197-204. http://www.biotaneotropica.org.br/v8n3/en/ abstract?article+bn02308032008.

Thorp JH, Thoms MC, Delong MD. The riverine ecosystem synthesis: Biocomplexity in river networks across space and time. River Res Appl. 2006; 22(2):123-47. http://doi. org/10.1002/rra.901

Torrente-Vilara G, Zuanon J, Leprieur F, Oberdorff T, Tedesco PA. Effects of natural rapids and waterfalls on fish assemblage structure in the Madeira River (Amazon Basin). Ecol Freshw Fish. 2011; 20(4):588-97. http://doi.org/10.1111/j.16000633.2011.00508.x

Vitorino Júnior OB, Fernandes R, Agostinho CS, Pelicice FM. Riverine networks constrain $\beta$-diversity patterns among fish assemblages in a large Neotropical river. Freshw Biol. 2016; 61(10):1733-45. http://doi.org/10.1111/fwb.12813
Ward JV, Tockner K. Biodiversity: Towards a unifying theme for river ecology. Freshw Biol. 2001; 46(6):807-19. https://doi. org/10.1046/j.1365-2427.2001.00713.x

Winemiller KO, Flecker AS, Hoeinghaus DJ. Patch dynamics and environmental heterogeneity in lotic ecosystems. J North Am Benthol Soc. 2010; 29(1):84-99. https://doi.org/10.1899/08-048.1

Winemiller KO, Jepsen DB. Effects of seasonality and fish movement on tropical river food webs. J Fish Biol. 1998; 53:267-96. https:// doi.org/10.1111/j.1095-8649.1998.tb01032.x

Zaniboni-Filho E, Meurer S, Shibatta OA, Nuñer APO. Catálogo ilustrado de peixes do alto rio Uruguai. Florianópolis: Editora da UFSC; 2004.

Zaniboni-Filho E, Schulz U. Migratory fishes of the Uruguay river. In: Carosfeld J, Harvey B, Ross C, Baer A, editors. Migratory fishes of the South America: Biology, social importance and conservation status. Victoria: World Fisheries Trust; 2003. p.157-94.

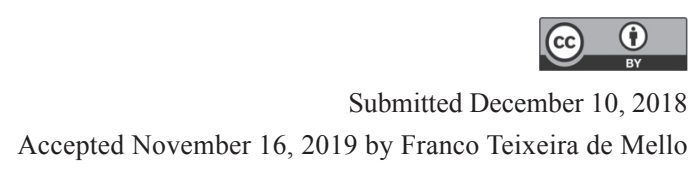

